\title{
Development and Pathology of the Equine Mammary Gland
}

\author{
Katherine Hughes ${ }^{1}$ \\ Received: 18 July 2020 / Accepted: 16 November 2020 / Published online: 5 December 2020 \\ (C) The Author(s) 2020
}

\begin{abstract}
An understanding of the anatomy, histology, and development of the equine mammary gland underpins study of the pathology of diseases including galactorrhoea, agalactia, mastitis, and mammary tumour development. This review examines the prenatal development of the equine mammary gland and the striking degree to which the tissue undergoes postnatal development associated with the reproductive cycle. The gland is characterised by epithelial structures arranged in terminal duct lobular units, similar to those of the human breast, supported by distinct zones of intra- and interlobular collagenous stroma. Mastitis and mammary carcinomas are two of the most frequently described equine mammary pathologies and have an overlap in associated clinical signs. Mastitis is most frequently associated with bacterial aetiologies, particularly Streptococcus spp., and knowledge of the process of post-lactational regression can be applied to preventative husbandry strategies. Equine mammary tumours are rare and carry a poor prognosis in many cases. Recent studies have used mammosphere assays to reveal novel insights into the identification and potential behaviour of mammary stem/progenitor cell populations. These suggest that mammospheres derived from equine cells have different growth dynamics compared to those from other species. In parallel with studying the equine mammary gland in order to advance knowledge of equine mammary disease at the interface of basic and clinical science, there is a need to better understand equine lactational biology. This is driven in part by the recognition of the potential value of horse and donkey milk for human consumption, particularly donkey milk in children with 'Cow Milk Protein Allergy'.
\end{abstract}

Keywords Horse $\cdot$ Mammary gland $\cdot$ Mastitis $\cdot$ Milk $\cdot$ Pathology $\cdot$ Tumour

\section{Introduction}

The mammary gland, or udder as it may be referred to in ungulates, is a fascinating organ that, compared to many other organs, is subject to an unusually high level of postnatal development during puberty and the reproductive cycle [1]. Whilst the equine mammary gland is relatively less frequently affected by disease than the ruminant udder by mastitis, and the mammary gland of companion animal carnivores by neoplasia, both mastitis [2] and mammary tumours [3] do occur in horses. In addition, the equine mammary gland has interesting developmental features, such as the striking similarity of the equine mammary gland to the human breast. Recent studies have revealed novel insights into the identification and behaviour of equine mammary stem/progenitor cell (MaS/PC) populations that have potentially profound implications for the

Katherine Hughes

kh387@cam.ac.uk

1 Department of Veterinary Medicine, University of Cambridge, Cambridge, UK understanding of mammary tumourigenesis [4]. Furthermore, understanding of specific facets of the mammary postnatal developmental cycle, particularly involution, underpins husbandry strategies aimed at reducing the incidence of mastitis in mares. However, comprehensive reviews of equine mammary development, and pathology of the equine mammary gland, are currently sparse. Thus, this review will provide an exploration of the development, and gross and molecular pathology of the equine mammary gland, that together underpin clinical understanding of equine mammary disease pathogenesis. Where relevant, comparisons will be drawn with humans and other species of veterinary or experimental interest.

\section{The Equine Mammary Gland in Health}

\section{Gross Anatomy of the Mammary Gland}

The equine udder comprises one pair of mammae each with a teat. Each mamma is usually drained by two independent mammary ductal trees, although three may rarely occur [5]. 
Thus each teat typically has two orifices through which the main ducts discharge (Fig. 1) [6]. This is in contrast to the cow which has two pairs of inguinal mammae, each drained by one ductal system. Like the horse, sheep and goats have only one pair of inguinal mammae, although unlike the horse, but similar to the cow, these only have one ductal system per mamma [7]. Cats and dogs have four and five pairs of mammae respectively, with multiple ductal trees per mamma [8, 9]. Rabbits similarly have four or five pairs of mammae, each with 6-7 ductal systems [10].

In contrast to male ruminants that have rudimentary mammary structures, the majority of male horses lack teats [11]. However, some male donkeys have teats on their sheath [12] and this is also the case in some mules (A. Mclean, personal communication) [11].

\section{Prenatal Mammary Development}

The equine anatomical arrangement of one pair of inguinal mammae, each having two ductal trees [13], arises during foetal development. The embryonic mammary gland has ectodermal (epithelial) and mesenchymal (stromal) cellular compartments. Across species, initial mammary development is considered to be characterised by the formation of ventral milk lines, exhibiting an anterior-to-posterior alignment, and composed of multi-layered ectoderm [14] although the formation of the milk line is somewhat controversial in the horse [6, 11]. Complex interplay between ectodermal and mesenchymal compartments results in thickenings of ectoderm called mammary placodes developing at expected locations along the milk line [14] and these are suggested to be present at $7.9 \mathrm{~cm}$ foetal crown-rump length in the horse [6]. The cells of the mammary placode then differentiate into the mammary bulb at approximately $8 \mathrm{~cm}$ equine foetal crown-rump length [6].
At approximately $9.5 \mathrm{~cm}$ foetal crown-rump length, two tendrils of cells arise from the mammary bulb and grow into the underlying mesenchyme. These are called primary sprouts. Ensuing foetal development results in secondary sprouts developing from the primary sprouts, and it is the descending secondary sprouts that give rise to the teat cistern and ductal tree. A lateral secondary sprout forms a pilosebaceous sprout that develops into primary, and on occasion secondary, hair follicles together with a sebaceous gland. The associated hair(s) exit the teat adjacent to the mammary duct that also originated from the primary sprout. Thus development of the equine mammary gland is characterised by formation of two mammolobular-pilo-sebaceous units (MPSU) per teat, each MPSU comprising a galactophorous duct, a mammary hair, and a sebaceous gland [6]. Intriguingly, the immature domestic cat also exhibits MPSU at approximately one week after birth, but the pilosebaceous component regresses by approximately 3 months of age [6]. By contrast, in the horse the MPSU persist postnatally and can be clearly observed in adult horses (Fig. 1).

\section{Equine Mammary Gland Structural Organisation and Histology}

The equine mammary gland is characterised by collagenous stroma in which the epithelial structures are arranged in terminal duct lobular units (TDLUs) similar to the TDLUs of the human breast [15]. The ruminant mammary gland is also organised into TDLUs [16] that are from time to time described as analogous terminal duct units [17, 18]. A TDLU comprises a group, or lobule, of blind-ending mammary acini and both intralobular and extralobular portions of the subtending terminal duct, which together comprise the functional unit of the mammary gland (Fig. 2). In the human breast TDLUs drain into the intralobular terminal ducts, and subsequently the extralobular terminal ducts, subsegmental ducts,

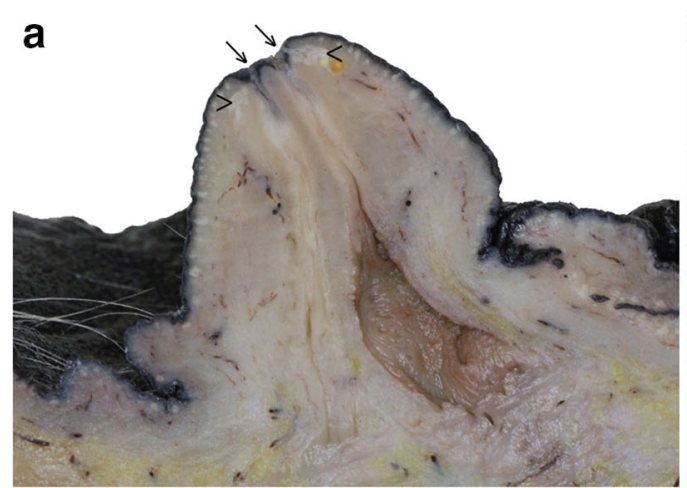

Fig. 1 The equine mammary gland is characterised by formation of two mammolobular-pilo-sebaceous units (MPSU) per teat. Parasagittal section through the distal mammary gland and teat of a mare (a) and corresponding histological section (b) demonstrating the two openings of the ductal systems (arrows) and corresponding sebaceous glands

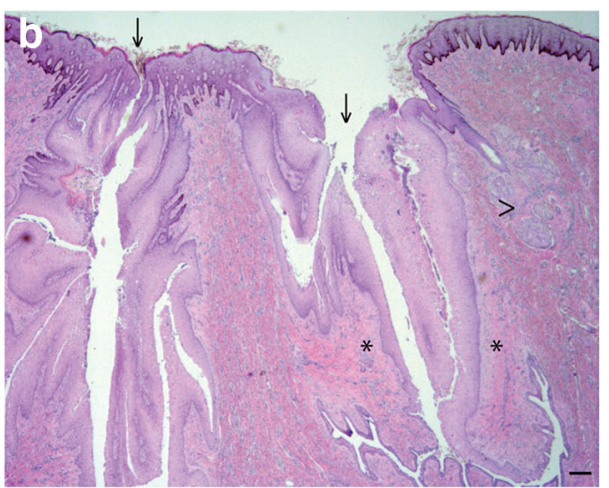

(arrowheads). b. Only one sebaceous gland unit (arrowhead) is visible in the histological section. Note the sparsely cellular connective tissue surrounding the teat canal $(*)$. Haematoxylin and eosin stain. Scale bar= $200 \mu \mathrm{m}$ 


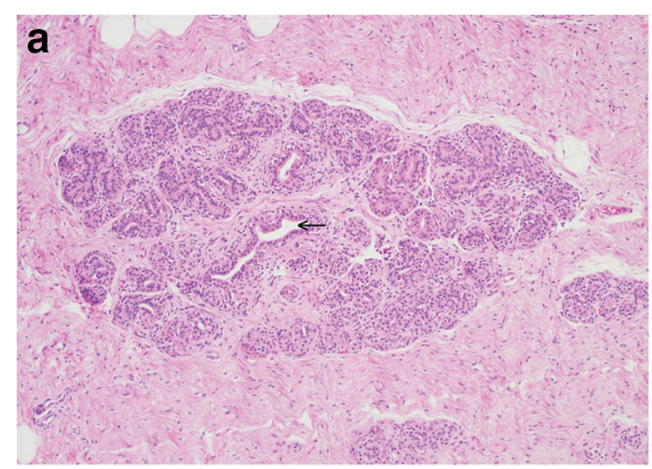

Fig. 2 The equine mammary gland is characterised by terminal duct lobular units (TDLUs) supported by collagenous stroma. a. Quiescent mammary tissue from a 28 year-old thoroughbred cross mare of unknown reproductive history. The lobular arrangement of the mammary acini and ducts (arrow) is clearly apparent. b. Quiescent mammary tissue from a 12 year-old warmblood of unknown reproductive history. The bilaminar

and segmental ducts, which eventually converge to form the primary mammary ducts [15]. Murine mammary ducts have bulb-shaped structures called terminal end buds that are key in coordination of subsequent duct growth and branching [19, 20].

Mammary ducts are bilayered, with basal and luminal layers of mammary epithelial cells visible [10, 21, 22] (Fig. 2 b; Fig. 3). Unlike the basal epithelial cells of stratified squamous epithelia, mammary basal epithelial cells exhibit characteristics common to smooth muscle cells, including expression of alpha smooth muscle actin ( $\alpha$-SMA) [23-25], and hence may be referred to as 'myoepithelial' cells to emphasise their contractile phenotype [26, 27]. As would be anticipated,

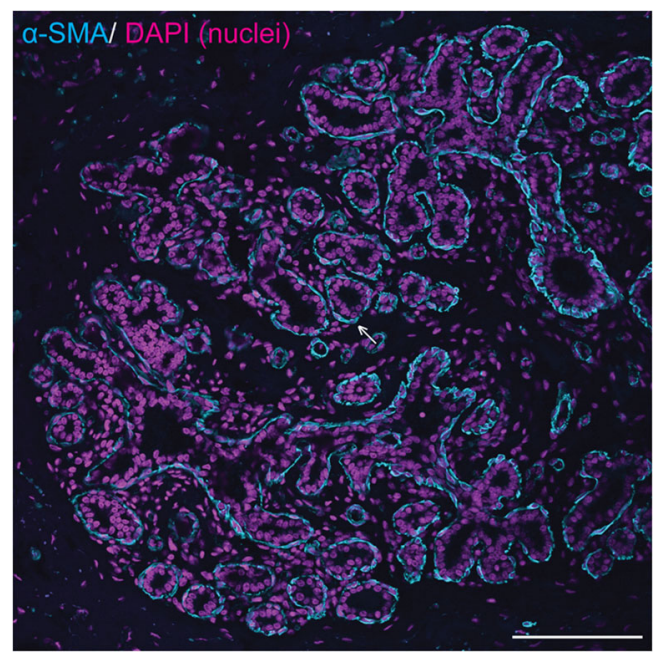

Fig. 3 Equine mammary epithelial cells exhibit a bilaminar arrangement, with expression of alpha smooth muscle actin $(\alpha-$ SMA) in the outer myoepithelial layer. Immunofluorescence staining for $\alpha$-SMA (cyan) and DNA (DAPI; magenta) in equine mammary tissue from a 16 year-old thoroughbred mare. Arrow indicates myoepithelial cell expressing $\alpha$-SMA. Scale bar $=116 \mu \mathrm{m}$. Image is representative of three biological repeats from different mares

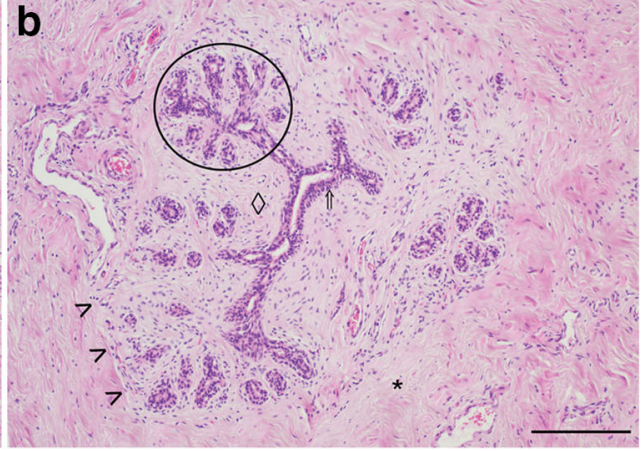

arrangement of epithelial cells within the ducts is distinct (double arrow). A TDLU is encircled. Note the more cellular intralobular stroma (diamond) supporting TDLUs, and the more loose and sparsely cellular interlobular stroma $(*)$ which surrounds lobules. The border between the two types of stroma is particularly well-demarcated in this image (arrowheads). Haematoxylin and eosin stain. Scale bar $=200 \mu \mathrm{m}$

equine mammary myoepithelial cells also exhibit $\alpha$-SMA expression (Fig. 3) [28].

Basal and luminal mammary epithelial cells may also be distinguished by their expression of intermediate filaments, although this may vary between species and between locations within the mammary gland, for example expression of specific cytokeratins (CKs) may be different between epithelial cells in large ducts and those within a TDLU $[20,26]$. In humans, the high molecular weight cytokeratins CK5 and CK14, which can form heterodimers, are expressed in interlobular duct basal myoepithelial cells but are predominantly expressed in luminal epithelial cells in TDLUs [20,26]. By contrast, in the adult mouse mammary gland, CK5 and CK14 are considered to be expressed solely by myoepithelial cells [20,29]. In the adult rabbit mammary gland during pregnancy and lactation, CK14 is expressed predominantly in the epithelial basal compartment of ducts and sinus-like dilatations, but with occasional positive luminal epithelial cells [10]. Based on the currently available evidence, in the adult horse CK14 is similarly expressed predominantly in mammary basal epithelial cells [3, 30] (Fig. 4).

CK 7 and CK18 are expressed in luminal mammary epithelial cells in the human breast [31, 32]. In the adult horse, CK8/ 18 is also expressed in the luminal mammary epithelial cells, although expression is somewhat weak with a commercially available antibody [30]. Equine mammary luminal epithelial cells similarly express CK8 [28].

In the vast majority of investigations of equine mammary biology and pathology, antibodies raised against epitopes in species other than the horse will be utilised. The above discussion of variable expression of intermediate filaments between different species highlights the need for particularly stringent evaluation of such experiments, and the requirement for appropriate control tissue [30]. An ideal positive control tissue will also include areas where the antigen of interest is not expressed (negative internal control) [33]. For example, 


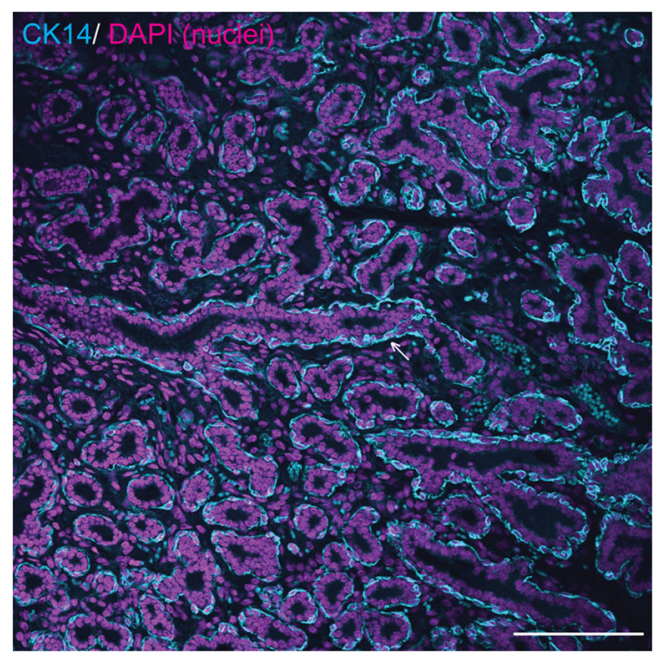

Fig. 4 Equine mammary myoepithelial cells express cytokeratin 14 (CK14). Immunofluorescence staining for CK14 (cyan) and DNA (DAPI; magenta) in equine mammary tissue. Arrow indicates ductal basal epithelial cell expressing CK14. Scale bar $=116 \mu \mathrm{m}$. Image is representative of three biological repeats from different mares

the basal aspect of stratified epithelium can be used as a positive control for CK14 [26] together with the myoepithelial cells of nearby dermal apocrine glands, whilst the apocrine gland luminal epithelia are a negative internal control for CK14. Where possible it is desirable to perform confirmatory western blotting to demonstrate detection of an appropriately sized protein in the species of interest. The variability of mammary intermediate filament expression between different species also represents a major challenge in the delineation of MaS/PCs in species such as the horse, a subject that will be examined in more detail later.

The stroma of the equine mammary gland is arranged into more densely packed collagenous and cellular intralobular stroma in which TDLUs are embedded, and looser and more sparsely cellular interlobular stroma which surrounds lobules (Fig. 2b). Interestingly, a similar pattern is seen in ruminants, with intralobular stroma and comparable 'near stroma', and interlobular stroma and equivalent 'far stroma', recognised [7, $16,17,34,35]$. The equine and ruminant mammary stroma thus shows similarities to the human breast [15]. By contrast, the stroma of the mouse mammary gland is adipocyte-rich and quite different from that of the horse, human and ruminant [20].

As already described, each equine teat exhibits two MPSU. Similar to ruminants [36], the equine mammary teat canal is surrounded by sparsely cellular connective tissue and smooth muscle fibres (Fig. 1).

\section{Equine Postnatal Mammary Development}

As in other species, the mammary gland exhibits a dramatic level of tightly-regulated postnatal growth and development, particularly associated with physiological events such as puberty, pregnancy, lactation, and post-lactational regression. Such growth and development is coordinated by a number of factors including steroid hormones [37] and the STAT family of transcription factors [38]. Unfortunately, compared to experimental rodents and production ruminants, there is little specific data available regarding equine mammary postnatal development. Given the presence of significant species differences in mammary gland biology, extrapolation of results across species, particularly from rodent models, necessitates significant caution and is not always appropriate [39]. However, some general comments may be made from comparison with other species.

To better describe the postnatal developmental fluctuations in the human breast, some authors classify breast lobules according to their degree of complexity. Type 1 lobules are the simplest and comprise a terminal duct surrounded by a grouping of alveolar buds. Alveolar buds are considered to be more developed than a terminal end bud but less complex than the terminal structures of the mature mammary gland known as acini. Type 2 and 3 lobules are distinguished by an increased lobular area and more numerous alveolar buds that resemble ductules. In humans, lobule formation occurs 1-2 years after puberty, and the breasts of nulliparous women are predominantly composed of type 1 lobules, with smaller numbers of type 2 and 3 lobules [40]. Similar lobules can be observed in other species that exhibit TDLUs, including horses (Fig. 2). Interestingly, proportions of type 1, 2, and 3 lobules present in the porcine mammary gland have been demonstrated to be similar to the proportions in the human breast [41]. During pregnancy in women, a growth phase heralds proliferation of distal elements of the ductal tree, with ductules developing into acini, a signature that marks conversion of type 3 lobules into type 4 lobules [22].

These structural changes within the breast or mammary gland are underpinned by hormonal influences and through experiments carried out in ovariectomized pigs, oestrogen has been demonstrated to promote progression between type 1,2 and 3 lobules [41]. Experiments in ovariectomized calves may similarly have relevance to the understanding of hormonal influences on postnatal mammary gland development. In this species it has been demonstrated that ovariectomy causes a reduction in mammary parenchymal mass [42]. Furthermore, prepubertal ovariectomy abrogates progesterone receptor expression in mammary epithelial cells and reduces the intensity of oestrogen receptor expression. Tissue from ovariectomized calves exhibits reduced abundance of Ki67, a nuclear protein expressed in cells that are actively cycling, both in the mammary epithelial cells and in the stroma [43].

As is evident from the above discussion, the relative paucity of specifically equine-focussed information regarding the molecular biology of mammary postnatal development highlights this as an area where future studies might be usefully directed. 


\section{Equine Lactation and Milk Biology}

High concentrations of oestrogens and progestogens occur during pregnancy [13]. The final week of pregnancy heralds a marked rise in plasma prolactin concentration. Prolactin levels remain elevated to a variable degree in early lactation, before an eventual reduction to basal levels by 1-2 months post foaling [44]. Prolactin binding to its receptor activates the transcription factor Signal Transducer and Activator of Transcription 5 (STAT5) which initiates expression of milk protein genes in mammary epithelial cells [1]. Further information regarding hormonal regulation of lactation has been previously collated [13].

\section{Milk Let Down}

When a mother suckles her offspring, the maternally derived neuropeptide oxytocin binds to its cognate receptor expressed on mammary basal (myoepithelial) cells stimulating intracellular calcium signalling that results in contraction of the myoepithelial cells and milk expulsion [45]. This process is known as 'milk let down'. Anticipation of nursing, stimulation of the udder by the foal, and nursing itself, can all precipitate release of oxytocin from the posterior pituitary $[13,46]$.

\section{Colostrum}

Colostrum is the first form of milk produced by the mammae. On the first day of lactation, equine colostrum comprises approximately $25 \%$ total solids and $2.85-2.93 \%$ fat. Concentration of vitamins $A, D_{3}, K_{3}$ and $C$ is 1.4-2.6 times higher than in normal milk [47]. Total protein concentration in the region of $16 \%$ has been documented [48]. Analysis of colostrum, and milk samples taken during the first week of lactation, has revealed that the oligosaccharide profile of equine milk has shared features with human, bovine, porcine, and caprine milk, but also distinct differences [49, 50].

Mean colostral concentrations of IgG, IgM, and IgA have been reported as $8911.9 \pm 6282.2 \mathrm{mg} / \mathrm{dl}, 957 \pm 1088.1 \mathrm{mg} / \mathrm{dl}$, and $122.9 \pm 77.3 \mathrm{mg} / \mathrm{dl}$, respectively [51]. Density of colostrum has been used as a surrogate read-out of IgG levels and, for equine colostrum, has been suggested to be $1060 \mathrm{~g} / 1$ [52]. In the cow, refractive index has also been shown to correlate with IgG concentration [53] and it is asserted that good quality equine colostrum should have a $23 \%$ brix value [52]. As might be anticipated, weight loss in the pregnant mare may impact colostrum quality and milk yield [54]. It is possible that the quality of colostrum produced by older mares may be reduced [55].

\section{Milk}

Relative to the milk of most domestic species, total proteins, fat, inorganic salts, and energy are low in equine milk, but mare's milk is rich in lactose $[13,56]$ and lactose concentration may slowly increase as lactation progresses [57]. Caseins comprise approximately $80 \%$ of bovine total milk proteins, but by contrast equine milk contains less casein $(\sim 55 \%$ of total protein) and more whey proteins [56].

Interestingly, compared to the milk of ruminants, horse and donkey milk are considered to be more similar in composition to human milk [56]. Donkey milk is proposed as a less allergenic alternative to cow's milk for children with 'Cow Milk Protein Allergy' [58, 59]. This is in part due to the aforementioned lower levels of $\alpha$ s1-casein compared to cow's milk [58]. Furthermore, for human infants, taurine is as an essential metabolite and whilst equine milk has ten times less taurine than human milk, it has notably more taurine than bovine milk [56].

A number of factors, including genetic and environmental considerations, and stage of lactation, likely influence the composition of mare's milk. Mare age may be a contributory factor, and interestingly, milk composition may also influenced by breed, although this is a somewhat controversial suggestion (reviewed in [56]).

\section{Cytology of Colostrum and Milk}

Cytological examination of equine colostrum or milk may be undertaken. Smears of colostrum collected within $12 \mathrm{~h}$ of parturition are characterised by a granular or homogeneous protein background with fragmented nuclear debris and red/ purple spheres. Clear lipid vacuoles and epithelial cells with a large vacuole (signet or secretory cells) may be detected in some cases. Smears of equine milk again have a proteinaceous background and are either acellular or may contain scarce neutrophils [60, 61].

\section{Post-Lactational Mammary Regression or Involution}

The term post-lactational mammary regression, or involution, describes the dramatic changes occurring within the mammary gland at the end of lactation [38]. Across species, in both experimental and natural settings, involution is initiated following weaning that may be abrupt or gradual [62]. Understanding the biological process of mammary postlactational regression is important as it underpins husbandry measures taken around the time of weaning to reduce mastitis incidence in mares.

The process of involution has been most extensively characterised following abrupt, or forced, weaning in rodents. From such studies it has been demonstrated that involution is a bipartite process. The first, reversible phase is driven by local factors, presumably stimulated by milk accretion [63] resulting in increased intraluminal pressure [64]. These signals result in extensive STAT3-regulated cell death $[65,66]$, occurring by a lysosomal-mediated cell death pathway [67-69]. Further cell death also occurs in the second irreversible phase 
of involution. This phase exhibits hallmarks of profound tissue remodelling and immune cell infiltration, that together have caused it to be likened to a healing wound [70-72]. During this irreversible remodelling large numbers of leucocytes, particularly macrophages [24, 25, 73], are present. The macrophages exhibit a STAT3-dependent immunomodulatory phenotype [74] and participate in involutionassociated neo-lymphangiogenesis [75]. Cytology affords a valuable window into mammary involution in the mare and correlates with these observations from mice in that vacuolated macrophages predominate in secretions collected during early involution. By contrast, secretions from later involution are characterised by cells that are small and dark, with minimal cytoplasm. These may be shrunken epithelial cells or lymphocytes [61].

Potentially pertinent to the likely progression of involution in mares, cell death also occurs during involution induced by natural weaning in experimental rodents although the cell death dynamics may differ, with slower onset of cell death in the context of natural weaning [76]. Also relevant to some mares, that will be pregnant during involution, is the recognition that involution in dairy cows often proceeds with a 'parallel pregnancy signature' $[7,35]$. In mice, concurrent pregnancy reduces the magnitude of cell death initiated following abrupt weaning [77] although cell death occurs earlier in mice that are subjected to natural weaning whilst pregnant [76]. Overall, it has been observed that mammary involution in remated mice is quite different from the process observed in non-pregnant rodents [76] and similarly it is likely that the dry period in dairy cows represents not only a phase of cell death but also a period of epithelial cell renewal $[78,79]$. Although dairy cows have been selectively bred for high milk yields, it would seem possible, or even likely, that the mammary gland of mares exposed to the hormonal and cytokine milieu of concurrent pregnancy and involution may also exhibit dual features of cell death and cell proliferation and have a distinct time course and gene expression patterns compared to involution in non-pregnant mares.

\section{Senile Mammary Involution or Lobular Involution}

In addition to post-lactational involution resulting from abrupt or gradual weaning, a form of mammary involution that is not associated directly with the cessation of lactation occurs at the end of the reproductive life of an animal [80]. In humans this senile mammary involution may be associated with a reduction in the number of type 3 mammary lobules, potentially reflecting the regression of type 3 lobules to a type 2 and 1 lobule phenotype [22].

\section{Equine Mammary Stem/Progenitor Cells}

During embryonic development, the mammary gland is generated from multipotent mammary stem cells, and a subpopulation of MaS/PCs persist postnatally and are responsible for the dramatic postnatal mammary gland development associated with events such as puberty and pregnancy. The role of MaS/PCs and whether they contribute to only the luminal or basal epithelial lineages (unipotency) [81] or both lineages (bipotent $\mathrm{MaS} / \mathrm{PCs}$ ) remains controversial even in the mouse. This concept has been recently reviewed $[82$, 83], and will not be discussed further here.

Equine MaS/PCs have attracted interest due to the low incidence of mammary neoplasia in this species. They also likely contribute to maintenance of epithelial cell numbers during lactation [84]. However, there are a number of challenges surrounding working with MaS/PCs outside of the rodent and human arenas, and one particular issue is that panels of markers used to identify MaS/PCs in one species may not necessarily be applied with confidence to a different species [85]. One methodology that is not reliant on marker identification is to digest mammary tissue and to generate floating cell colonies called mammospheres enriched in MaS/PCs [84, 86]. Using this technique, it has been shown that equine mammospheres have different growth dynamics compared to canine mammospheres, and in particular, the mammosphere formation efficiency exceeds that of the canine mammospheres and is maintained for a much increased number of passages [87]. Intriguingly, microvesicles appear to contribute to the self-renewal signals through Wnt signalling pathways [87]. When compared to their canine counterparts, equine MaS/PCs also respond differently to agents causing DNA damage, activating the intrinsic and extrinsic apoptotic pathways. This may be a property contributing to the lower mammary cancer incidence in this species [4].

\section{Pathology of Diseases Affecting the Equine Mammary Gland}

\section{Galactorrhoea}

The term 'galactorrhoea' refers to inappropriate secretion of milk or a milk-like product from the mammary gland and encompasses both precocious secretion during pregnancy and inappropriate secretion in the absence of a prior lactation event [13]. These two different manifestations of galactorrhoea will be considered in turn below.

\section{Precocious Lactation}

In pregnant mares, precocious mammary development and lactation have been suggested to be often associated with imminent abortion, placentitis, or separation of the placenta [13] although spontaneous resolution of premature lactation in a mare carrying a viable foal and mummified foetus has been documented [88]. A report has also described premature udder 
development and lactation in a mare found to be carrying a dead foetus and receiving weekly administration of longacting progesterone [89]. Notably, if mares develop galactorrhoea prior to foaling, there may be impaired passive transfer of immunoglobulins to the foal via colostrum due to loss of immunoglobulins in the earlier secretions [13, 88].

\section{Inappropriate Lactation in Non-pregnant Mares}

Mammary development and attendant inappropriate lactation may be observed in neonatal foals, where, as in newborns of other animal species and babies, the secretory product is colloquially referred to as 'witch's milk' [11]. This phenomenon has been attributed to exposure to the mare's lactogenic hormones [13]. Interestingly, as alluded to above, secretion of 'witch's milk' has been detected in a notable proportion of human babies, where the pathogenesis of secretion is thought to be similar to that in foals [90]. Adult mares may also occasionally be presented with galactorrhoea [91] with potential causes including a lack of dopaminergic suppression of prolactin secretion, leading to increased prolactin levels, occurring secondary to equine pituitary pars intermedia dysfunction (equine Cushing's disease), and exposure to oestrogens. Many cases, however, remain idiopathic [91-93].

\section{Agalactia}

Agalactia describes the state where a female that should be producing colostrum or milk has an absence of lactation [13]. The condition has been described in a variety of species including dogs and cats, where the literature distinguishes two forms of agalactia according to underlying pathogenesis. Temporary agalactia is recognised in situations such as parturition in primiparous females or those undergoing premature caesarean sections and is symptomatic of a lack of synchrony between mammary development and parturition. By contrast, true agalactia reflects persistent lack of lactation with a variety of potential underlying aetiologies which may pertain either directly to the patient or to the patient's environment [94]. In addition to small domestic carnivores, agalactia has been described in diverse species including pigs [95, 96], rabbits [97, 98], and horses [99, 100].

The clinical impact of agalactia in the horse can be profound as it may result in failure of passive transfer and insufficient nutrition for the foal [13]. Authors of equine texts distinguish between failure of milk let-down in maiden or stressed mares [13], which might be termed temporary agalactia by the above small animal definitions, and causes of true agalactia. In horses, mycotoxicosis is a notable cause of true agalactia and is typically associated with the consumption of the ergot alkaloids produced by the fungi Claviceps purpurea and Neotyphodium coenophialum (synonym Acremonium coenophialum). The latter infects Festuca arundinacea (synonym Festuca elatior). Hypogalactia or agalactia occurs secondary to decreased prolactin secretion and retarded mammary gland development [99-101]. The cause of decreased prolactin secretion is the dopamine agonist- and serotonin antagonist-effects of the alkaloids [13]. Streptococcus equi infection has also been implicated as a cause of true agalactia [102]. In other cases of equine agalactia, it is not possible to establish the underlying cause of the syndrome [103].

\section{Mastitis}

\section{Clinical Presentation and Diagnosis}

Mastitis is an uncommon condition in horses [104] that most frequently occurs during lactation, or during post-lactational regression associated with weaning, and is therefore most commonly seen in the summer or autumn months [105]. In addition, mastitis may occur in association with milk build up relating to illness or loss of a foal, and may also be diagnosed in pregnant mares [106], non-pregnant dry mares [107], young fillies $[108,109]$ and neonates [110]. The relatively low frequency of mastitis in mares is a phenomenon that has attracted interest and discussion (Table 1) [104, 108].

Mares from a range of breeds have been reported as affected by mastitis. These include thoroughbreds, standardbreds, quarter horses and ponies [107, 109]. It is likely that the reported breeds are, to an undetermined degree, a reflection of prevalence of breeds in the caseloads of institutions where authors have studied mastitis.

The majority of mares are likely to present with unilateral disease, and in some cases only one ductal tree within a

Table 1 Factors implicated in the low frequency of mastitis in mares

\begin{tabular}{lc}
\hline Factor & Reference \\
\hline Anatomical considerations & \\
$\quad$ Size of udder (smaller than cows) & {$[104]$} \\
Udder more concealed & {$[108]$} \\
& {$[104]$} \\
Teats less prone to trauma and infection & {$[104]$} \\
& {$[119]$} \\
Physiological considerations & \\
Small capacity of udder leading to frequent emptying & {$[104]$} \\
Short lactation period & {$[108]$} \\
Hyopthetical immunological or endocrine influences & {$[104]$} \\
Husbandry factors & \\
Small capacity of udder leading to frequent emptying & {$[104]$} \\
$\quad$ in animals that are milked & {$[108]$} \\
Husbandry of mare and foal & {$[108]$} \\
Under-reporting due to poor identification of & \\
$\quad$ subclinical and low grade cases
\end{tabular}


mamma may be affected $[2,109]$. In one study of 28 cases, $50 \%$ of patients exhibited temperature exceeding $38^{\circ} \mathrm{C}[2]$. Swelling of the mammary gland, local heat, pain, purulent discharge and ventral oedema are common clinical signs. More severe cases may be accompanied by systemic signs of illness including depression, anorexia, and even ipsilateral hind limb lameness $[2,109]$. Importantly, there is considerable overlap between many of these local and systemic clinical signs and those of mammary neoplasia (see next section).

Diagnosis is based on a combination of clinical signs, microbial culture and cytological evaluation. The cytological picture is usually one of myriad viable or degenerate neutrophils, necrotic material, and potentially other unidentifiable degenerate cells [60]. Importantly, bacteria are only detectable cytologically in approximately $30 \%$ of cases but conversely, the cytological picture may be very useful in diagnosing cases of mastitis where culture is negative [2] [60]. In addition, a minority of mares, likely those with systemic signs, may show neutrophilia and hyperfibrinogenaemia [2, 109].

\section{Causes}

Bacteria are the most commonly identified aetiological agents of equine mastitis. Whilst a range of gram positive and gram negative bacteria have been implicated, in one study in the USA Streptococcus spp. were the most frequently reported cause [2]. Cases of mastitis caused by Corynebacterium spp., Streptococcus spp., and Staphylococcus spp. may progress to abscess formation in some instances [5, 61]. Interestingly, it has recently been suggested that mammary abscesses may be more common mares from regions in which pigeon fever, caused by Corynebacterium pseudotuberculosis, is endemic [5]. Indeed, equine mammary abscesses from which C. pseudotuberculosis has been cultured have been previously reported [111]. Mammary infection with Staphylococcus spp. may elicit granulomatous inflammation, with a very distinctive pattern of response to the bacteria known as botryomycosis [93, 112].

In addition to bacterial causes of mastitis, fungal, parasitic, and toxic aetiologies have also been recorded. Fungal agents causing equine mastitis include Coccidioides immitis [113] and Blastomyces dermatitidis [114] whilst Halicephalobus deletrix and Cephalobus spp. are examples of parasitic aetiologies [115, 116]. In addition, there is a possibility that cutaneous habronemiasis [117] may affect the skin overling the mammary gland, or superficial portions of the gland itself. Avocado (Persea americana) is a potential mastitis-causing agent [118].

\section{Concepts of Mammary Gland Biology that Underpin Prevention of Equine Mastitis}

The main facets of mastitis prevention in horses focus dually on general husbandry measures and nutrition of mare and foal.
In terms of husbandry, attentive udder monitoring and cleaning, and instigating husbandry measures that reduce the risk of acquisition of traumatic lesions, are both important. Implied in udder cleaning is adoption of measures to reduce the burden of flies and insects that may have a role in mastitis pathogenesis. Recognition of the importance of mammary acinar distension in the initiation of the involution process [63, 64] (see section on involution above) underpins advice to clients not to milk the mare after weaning [5].

There are two aspects of mastitis prevention specifically concerning nutrition. The first is the need to reduce mare dry matter intake at the point of drying-off to reduce milk production [5]. If the mare is fed excessively during the weaning phase, the gland may become inflamed and hardened, with the induration resolving gradually over time [119]. Providing creep feed for foals prior to drying off is also important in mastitis prevention [5]. Drying off is effectively synonymous with a forced involution in the experimental context. By providing generous creep before this point, a natural weaning process is fostered prior to forced involution and this is likely to reduce mastitis incidence.

\section{Mammary Tumours}

\section{Clinical Presentation and Diagnosis}

Equine mammary tumours are rare [3] (reviewed in [120]), predominantly of epithelial origin, and are, in the majority of cases, malignant, although a mammary adenoma has also been documented [121]. The limited data available suggest that the prognosis is poor for mares diagnosed with this tumour type, with the potential for metastasis to regional lymph nodes and other organs [117, 122, 123].

Laterality, the dominance of one side over the other, has been interrogated in human breast cancer [124, 125]. In the case of equine mammary tumours, insufficient cases have been recorded to allow any conclusions to be drawn regarding laterality, but there is a necessity, therefore, to carefully record such information, so that data from multiple reports can be collated.

The postnatal mammary developmental cycle, incorporating dramatic waves of proliferation, cell death and remodelling as described earlier, fundamentally impacts susceptibility to mammary tumourigenesis in humans. A full-term birth at an early age and prolonged breast feeding both confer protective effects, whereas pregnancy and involution are periods associated with an increased risk of tumour development [126]. At least three pregnant mares with concurrent mammary neoplasia have been reported $[127,128]$ and recently a lactating mare that was presented with a mammary comedocarcinoma has been described [129]. Similar to the situation with laterality, no conclusions can currently be drawn regarding impact of mare reproductive history on 
mammary tumour development. However, with meticulous data recording and collaborative efforts, eventually sufficient data may exist to facilitate such investigations [30].

At the time of presentation to the clinician, equine mammary masses may be painful [130] or non-painful [131], and in some cases are accompanied by oedema ventrally [128, 132] or affecting the hind limbs [133]. In the case of animals with advanced metastatic disease at the point of clinical presentation, poor body condition or overt emaciation may be non-specific clinical signs [123, 128, 133]. Mares with pulmonary metastases may show signs of coughing or respiratory distress [130].

One key finding which emerges from the case reports and case series documenting this neoplastic entity is that mares with mammary tumours are frequently presented with clinical signs compatible with mastitis $[3,128]$ and distinction between mastitis and mammary neoplasia is an important facet of clinical assessment of mammary masses in the mare [30]. It has been suggested that misdiagnosis as mastitis is a notable cause of delay in achieving a diagnosis of an equine mammary tumour [134]. In this regard, it is important to note that cytology may be helpful in differentiating these two conditions if epithelial cells demonstrating unequivocal criteria of malignancy are aspirated $[128,135]$. However, attendant inflammation may accompany mammary tumours and so an inflammatory cytological picture does not rule out underlying neoplasia [134]. Presence of ulceration has been postulated to be a factor that should increase clinical suspicion of neoplasia rather than mastitis $[127,128,136]$. Unfortunately, whilst the above assertions are potentially helpful diagnostic pointers, many are based on weak evidence and the above discussion again highlights that it is imperative to perform larger, multi-centre studies to accumulate sufficient cases to recognise diagnostically helpful trends. Ultimately, a core or excisional biopsy is frequently required for definitive diagnosis [134].

In a large number of published cases euthanasia is undertaken, potentially motivated by welfare or economic considerations, or on the basis of a likely poor prognosis. Therefore, the number of cases for which true survival data is available is strikingly small. Whilst very little can be definitively concluded regarding prognosis, a notable subset of published equine mammary tumours exhibited evidence of visceral metastatic spread at post mortem examination $[3,28,123,127,130,133$, 136].

\section{Histopathological and Molecular Analyses}

One of the challenges for the histopathologist examining an equine mammary tumour is the current lack of a unifying diagnostic classification system. Given the spectrum of morphological variants encountered in the published literature, it is potentially feasible and advisable to currently follow the guidelines available for small companion animals [137].
Notably, a number of specific morphological variants described for feline and canine mammary tumours have been described in horses. For example, invasive micropapillary carcinoma [138] and ductal carcinoma [28] have both been documented.

Owing to the rarity of equine mammary carcinomas, very limited molecular analyses have been undertaken when compared to studies of mammary tumourigenesis in cats and dogs. Expression of intermediate filaments has been assessed in small numbers of equine mammary carcinomas and preliminarily indicates that carcinomas are heterogeneous, with documented examples of tumours expressing CK8 or CK18 (luminal epithelial markers), CK14 (basal marker), pancytokeratin, glial fibrillary acidic protein (GFAP) and vimentin, with varying degrees of intensity $[3,28,139]$. Positive staining for $\alpha$-SMA has also been reported [139]. Thus equine mammary carcinomas may have the potential to exhibit luminal or basal phenotypes perhaps analogous to those seen in breast cancer and mammary carcinomas in other species of veterinary importance.

Similarly, a subset of equine mammary carcinomas exhibit oestrogen receptor alpha positivity by immunofluorescence, which has been suggested to correlate with weak or absent expression of vimentin [3]. Tumour oncogenes and tumour suppressor genes have also attracted interest in the study of equine mammary neoplasia. STAT3 is a known breast oncogene [140-142] that may bestow a direct survival advantage on breast cancer cells in addition to modulating the tumour microenvironment to facilitate neoplastic cell survival and/or infiltration and invasion. In one study, $3 / 7$ equine mammary carcinomas exhibited nuclear STAT3 expression, implying transcriptional activation of STAT3 [3] (Fig. 5). By contrast to STAT3, p53 is a tumour suppressor gene for which inactivation through mutation confers resistance to apoptosis. Interestingly, in one mammary carcinoma mRNA levels of p53 were reduced compared to those observed in non-

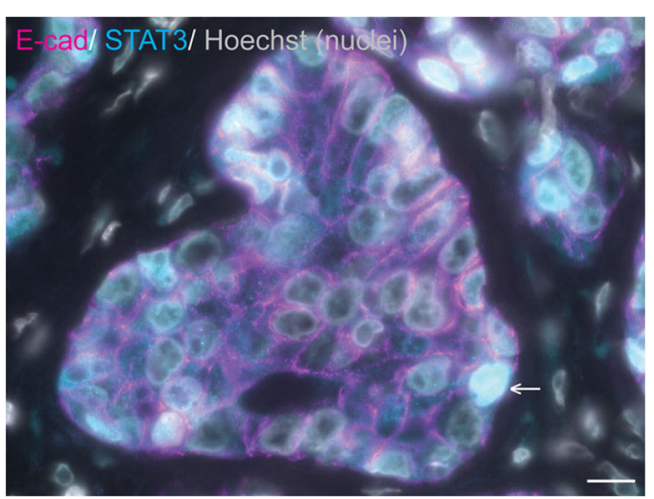

Fig. 5 STAT3 is expressed in a subset of equine mammary tumours. Immunofluorescence staining for E-cadherin (E-cad; magenta), STAT3 (cyan) and DNA (Hoechst; grey) in an equine mammary carcinoma. Data from [3]. Arrow indicates a neoplastic cell exhibiting nuclear STAT3 expression. Scale bar $=10 \mu \mathrm{m}$ 
neoplastic equine mammary tissue [139]. These studies, although limited in both number and scope, illustrate the enormous potential for future interrogation of the molecular profile of equine mammary tumours.

\section{Mammary Tumours of Non-mammary Origin}

Occasional infiltration of the mammary gland by carcinomas not specifically of mammary origin may occur. For example, vulval, perineal, and mammary invasion by a large squamous cell carcinoma has been described in an 18-year-old Appaloosa mare [143]. Additionally, as might be expected, neoplasms of non-epithelial origin may also arise in the equine mammary gland. Recorded examples have included a malignant fibrous histiocytoma [144], lymphoma [145], and malignant melanoma [146]. Sarcoids may also theoretically arise in the region of the mammary gland [117].

\section{Conclusions and Future Perspectives}

Whilst the equine mammary gland is not an organ commonly associated with disease, it is evident that pathology of this tissue, particularly mastitis and mammary neoplasia, frequently have profound effects on the welfare of mares and, in the case of mastitis, their foals. In addition, in some contexts, equine mammary disease has an economic, as well as a welfare impact. In the context of mammary tumours, the prognosis for affected mares may be bleak.

Due to the relatively low frequency of occurrence of many mammary diseases, much of the knowledge base in this field is built upon case reports and modest case series. Irrespective of an individual's perspective on the value of veterinary case reports, such publications do have significant inherent limitations and lie at the base of the evidence-based medicine pyramid [147]. This review underlines the need for complementary larger multi-centre investigations that will facilitate application of evidence-based veterinary medicine to diseases of the equine mammary gland [148].

Underpinning clinical studies of mammary gland disease are those investigations which probe the biology of this fascinating tissue. Here, again, there is a relative paucity of equinefocussed literature. As has been stated earlier, extrapolation of data from other species is not without difficulty and risk of false assumptions. In addition, a lack of equine-specific reagents necessitates significant care when using antibodies and experimental reagents developed for use in human or murine subjects.

Recent publications have begun to elucidate the intriguing biology of equine MaS/PCs whilst also demonstrating the pressing need to better characterise the equine mammary stem cell hierarchy. Results from these publications, together with the relative rarity of equine mammary tumours, suggest that equine MaS/PCs may have particular functional properties meriting further investigation. Comparative mammary gland biology focussing on the horse may reveal new insights into tumourigenesis with relevance for humans and other species.

The use of donkey milk as an alternative milk for children with 'Cow Milk Protein Allergy' reinforces the importance of the study of equine lactational biology and underlines the need to focus on the biology of the equine mammary gland. Indeed, there is a growing scientific field concerned with optimising milk production in donkeys maintained for this purpose [149, 150].

Unanswered questions regarding the equine mammary gland in health and disease therefore abound, and this organ remains an exciting subject of study for basic scientists and veterinarians alike.

\section{Materials and Methods for Unpublished Experiments}

Sections used for histology and immunofluorescence were obtained from tissues collected from cases examined post mortem by the anatomic pathology service of the author's institution, that were surplus to diagnostic requirements. Consent for retention of tissues for teaching and research purposes was granted at the time of submission for post mortem examination. Mammary tissue was collected in $10 \%$ neutral-buffered formalin. Following fixation, tissues were processed, sectioned and staining with haematoylin and eosin following standard histological protocols. Immunofluorescence staining for $\alpha$-SMA (ab124964, rabbit monoclonal [EPR5368] to $\alpha$-SMA, dilution 1:2000) (Abcam, Discovery Drive, Cambridge Biomedical Campus, Cambridge) and CK14 (ab7800, mouse monoclonal [LL002] to CK14, dilution 1:200) (Abcam) was carried out manually on unstained sections cut from formalin fixed paraffin embedded tissue. De-paraffinisation and antigen retrieval were performed using Agilent Envision Flex Target Antigen Retrieval Solution High pH (Agilent Technologies LDA UK Limited, Life Sciences and Chemical Analysis Group, Lakeside, Cheadle Royal Business Park, Stockport, Cheshire) in an Agilent PT link pre-treatment module (Agilent Technologies LDA UK Limited) for $20 \mathrm{~min}$ at $90^{\circ} \mathrm{C}$. Standard protocols for immunofluorescence were followed [151].

Acknowledgements The author gratefully acknowledges the excellent technical expertise of Debbie Sabin in the preparation of histology sections and unstained tissue sections for immunofluorescence. Some confocal microscopy images were acquired using equipment at the Cambridge Advanced Imaging Centre (CAIC) and the author thanks members of the CAIC for their advice and support. The author apologises to all investigators whose work unfortunately could not be cited due to constraints of space.

Author Contributions $\mathrm{KH}$ conceived and designed the review, performed experiments, and wrote the manuscript. 
Funding The author gratefully acknowledges The Pathological Society of Great Britain and Ireland for funding her current research (ICA 1019 02).

Data Availability The data that support the figures in this manuscript are available from the corresponding author upon reasonable request.

\section{Compliance with Ethical Standards}

\section{Conflict of Interest None.}

Consent to Participate Sections used for histology and immunofluorescence were obtained from tissues that were surplus to diagnostic requirements collected from cases examined post mortem by the anatomic pathology service of the Department of Veterinary Medicine, University of Cambridge. Consent for retention of tissues for teaching and research purposes was granted at the time of submission for post mortem examination.

\section{Consent for Publication Not applicable.}

Code Availability Not applicable.

Open Access This article is licensed under a Creative Commons Attribution 4.0 International License, which permits use, sharing, adaptation, distribution and reproduction in any medium or format, as long as you give appropriate credit to the original author(s) and the source, provide a link to the Creative Commons licence, and indicate if changes were made. The images or other third party material in this article are included in the article's Creative Commons licence, unless indicated otherwise in a credit line to the material. If material is not included in the article's Creative Commons licence and your intended use is not permitted by statutory regulation or exceeds the permitted use, you will need to obtain permission directly from the copyright holder. To view a copy of this licence, visit http://creativecommons.org/licenses/by/4.0/.

\section{References}

1. Hughes K, Watson CJ. The spectrum of STAT functions in mammary gland development. JAKSTAT. 2012;1(3):151-8.

2. McCue PM, Wilson WD. Equine mastitis-a review of 28 cases. Equine Vet J. 1989;21(5):351-3.

3. Hughes K, Scase TJ, Foote AK. Estrogen receptor and signal transducer and activator of transcription 3 expression in equine mammary tumors. Vet Pathol. 2015;52(4):631-4.

4. Ledet MM, Oswald M, Anderson R, Van de Walle GR. Differential signaling pathway activation in 7,12-dimethylbenz[a] anthracene (DMBA)-treated mammary stem/progenitor cells from species with varying mammary cancer incidence. Oncotarget. 2018;9(67):32761-74.

5. Canisso IF, Podico G, Ellerbrock RE. Diagnosis and treatment of mastitis in mares. Equine Vet Educ. 2020. https://doi.org/10.1111/ eve. 13228 .

6. Oftedal OT, Dhouailly D. Evo-devo of the mammary gland. J Mammary Gland Biol Neoplasia. 2013;18(2):105-20.

7. Hughes K, Watson CJ. The mammary microenvironment in mastitis in humans, dairy ruminants, rabbits and rodents: a one health focus. J Mammary Gland Biol Neoplasia. 2018;23(1-2):27-41.

8. Gimenez F, Hecht S, Craig LE, Legendre AM. Early detection, aggressive therapy: optimizing the management of feline mammary masses. J Feline Med Surg. 2010;12(3):214-24.
9. Sorenmo KU, Rasotto R, Zappulli V, Goldschmidt MH. Development, anatomy, histology, lymphatic drainage, clinical features, and cell differentiation markers of canine mammary gland neoplasms. Vet Pathol. 2011;48(1):85-97.

10. Hughes K, Watson CJ. Sinus-like dilatations of the mammary milk ducts, Ki67 expression, and CD3-positive T lymphocyte infiltration, in the mammary gland of wild European rabbits during pregnancy and lactation. J Anat. 2018;233(2):266-73.

11. Turner CW. The anatomy of the udder of the horse. In: The mammary gland I. The anatomy of the udder of cattle and domestic animals. Columbia: Lucas Brothers Publishers; 1952. p. 356-73.

12. Burnham SL. Anatomical Differences of the Donkey and Mule. In: American Association of Equine P, Lenz T, Palmer S, Robinson C, editors. Proceedings of the 48th annual convention of the American Association of Equine Practitioners, Orlando, Florida, December 4-8, 2002. Lexington: Veranda Communicaitons, Inc.; 2002. p. 102-9.

13. Chavatte-Palmer P. Lactation in the mare. Equine Vet Educ. 2002;14(S5):88-93.

14. Macias H, Hinck L. Mammary gland development. Wiley Interdiscip Rev Dev Biol. 2012;1(4):533-57.

15. Howard BA, Gusterson BA. Human breast development. J Mammary Gland Biol Neoplasia. 2000;5(2):119-37.

16. Rowson AR, Daniels KM, Ellis SE, Hovey RC. Growth and development of the mammary glands of livestock: a veritable barnyard of opportunities. Semin Cell Dev Biol. 2012;23(5):557-66.

17. Capuco AV, Ellis S, Wood DL, Akers RM, Garrett W. Postnatal mammary ductal growth: three-dimensional imaging of cell proliferation, effects of estrogen treatment, and expression of steroid receptors in prepubertal calves. Tissue Cell. 2002;34(3):143-54.

18. Capuco AV, Ellis SE. Comparative aspects of mammary gland development and homeostasis. Annu Rev Anim Biosci. 2013;1: 179-202.

19. Paine IS, Lewis MT. The terminal end bud: the little engine that could. J Mammary Gland Biol Neoplasia. 2017;22(2):93-108.

20. Dontu G, Ince TA. Of mice and women: a comparative tissue biology perspective of breast stem cells and differentiation. $\mathrm{J}$ Mammary Gland Biol Neoplasia. 2015;20(1-2):51-62.

21. Monaghan P, Perusinghe NP, Cowen P, Gusterson BA. Peripubertal human breast development. Anat Rec. 1990;226(4): 501-8.

22. Russo J, Russo IH. Development of the human breast. Maturitas. 2004;49(1):2-15.

23. Gugliotta P, Sapino A, Macri L, Skalli O, Gabbiani G, Bussolati G. Specific demonstration of myoepithelial cells by anti-alpha smooth muscle actin antibody. J Histochem Cytochem. 1988;36(6):659-63.

24. Stewart TA, Hughes K, Hume DA, Davis FM. Developmental stage-specific distribution of macrophages in mouse mammary gland. Front Cell Dev Biol. 2019;7:250.

25. Hitchcock JR, Hughes K, Harris OB, Watson CJ. Dynamic architectural interplay between leucocytes and mammary epithelial cells. FEBS J. 2020;287(2):250-66.

26. Gusterson BA, Ross DT, Heath VJ, Stein T. Basal cytokeratins and their relationship to the cellular origin and functional classification of breast cancer. Breast Cancer Res. 2005;7(4):143-8.

27. Hassiotou F, Geddes D. Anatomy of the human mammary gland: current status of knowledge. Clin Anat. 2013;26(1):29-48.

28. Hirayama K, Honda Y, Sako T, Okamoto M, Tsunoda N, Tagami $\mathrm{M}$, et al. Invasive ductal carcinoma of the mammary gland in a mare. Vet Pathol. 2003;40(1):86-91.

29. Gusterson BA, Stein T. Human breast development. Semin Cell Dev Biol. 2012;23(5):567-73.

30. Hughes $\mathrm{K}$. The known unknowns of equine mammary neoplasia. Equine Vet Educ. 2020. https://doi.org/10.1111/eve.13347. 
31. Santagata S, Thakkar A, Ergonul A, Wang B, Woo T, Hu R, et al. Taxonomy of breast cancer based on normal cell phenotype predicts outcome. J Clin Invest. 2014;124(2):859-70.

32. Santagata S, Ince TA. Normal cell phenotypes of breast epithelial cells provide the foundation of a breast cancer taxonomy. Expert Rev Anticancer Ther. 2014;14(12):1385-9.

33. Ramos-Vara JA. Principles and methods of immunohistochemistry. Methods Mol Biol. 1641;2017:115-28.

34. Beaudry KL, Parsons CL, Ellis SE, Akers RM. Localization and quantitation of macrophages, mast cells, and eosinophils in the developing bovine mammary gland. J Dairy Sci. 2016;99(1): 796-804.

35. Hughes K. Comparative mammary gland postnatal development and tumourigenesis in the sheep, cow, cat and rabbit: exploring the menagerie. Semin Cell Dev Biol. 2020. https://doi.org/10.1016/j. semcdb.2020.09.010

36. Hardwick LJA, Phythian CJ, Fowden AL, Hughes K. Size of supernumerary teats in sheep correlates with complexity of the anatomy and microenvironment. J Anat. 2020;236(5):954-62.

37. Fendrick JL, Raafat AM, Haslam SZ. Mammary gland growth and development from the postnatal period to postmenopause: ovarian steroid receptor ontogeny and regulation in the mouse. J Mammary Gland Biol Neoplasia. 1998;3(1):7-22.

38. Hughes K, Watson CJ. The multifaceted role of STAT3 in mammary gland involution and breast cancer. Int J Mol Sci. 2018;19: 1695. https://doi.org/10.3390/ijms19061695.

39. Hovey RC, McFadden TB, Akers RM. Regulation of mammary gland growth and morphogenesis by the mammary fat pad: a species comparison. J Mammary Gland Biol Neoplasia. 1999;4(1):53-68.

40. Russo J, Hu YF, Silva ID, Russo IH. Cancer risk related to mammary gland structure and development. Microsc Res Tech. 2001;52(2):204-23.

41. Horigan KC, Trott JF, Barndollar AS, Scudder JM, Blauwiekel RM, Hovey RC. Hormone interactions confer specific proliferative and histomorphogenic responses in the porcine mammary gland. Domest Anim Endocrinol. 2009;37(2):124-38.

42. Velayudhan BT, Huderson BP, McGilliard ML, Jiang H, Ellis SE, Akers RM. Effect of staged ovariectomy on measures of mammary growth and development in prepubertal dairy heifers. Animal. 2012;6(6):941-51.

43. Velayudhan BT, Huderson BP, Ellis SE, Parsons CL, Hovey RC, Rowson AR, et al. Ovariectomy in young prepubertal dairy heifers causes complete suppression of mammary progesterone receptors. Domest Anim Endocrinol. 2015;51:8-18.

44. Worthy K, Escreet R, Renton JP, Eckersall PD, Douglas TA, Flint DJ. Plasma prolactin concentrations and cyclic activity in pony mares during parturition and early lactation. J Reprod Fertil. 1986;77(2):569-74.

45. Stevenson AJ, Vanwalleghem G, Stewart TA, Condon ND, Lloyd-Lewis B, Marino N, et al. Multiscale imaging of basal cell dynamics in the functionally mature mammary gland. Proc Natl Acad Sci U S A. 2020;117:26822-32. https://doi.org/10.1073/ pnas.2016905117.

46. Sharma OP. Release of oxytocin elicited by suckling stimulus in mares. J Reprod Fertil. 1974;37(2):421-3.

47. Salamon RV, Salamon S, Csapo-Kiss Z, Csapo J. Composition of mare's colostrum and milk I. fat content, fatty acid composition and vitamin contents. Acta Universitatis Sapientiae, Alimentaria. 2009;2(1):119-31.

48. Csapo J, Salamon S, Loki K, Csapo-Kiss Z. Composition of mare's colostrum and milk II. Protein content, amino acid composition and contents of macro-and micro-elements. Acta Universitatis Sapientiae, Alimentaria. 2009;2(1):133-48.

49. Difilippo E, Willems HA, Vendrig JC, Fink-Gremmels J, Gruppen $\mathrm{H}$, Schols HA. Comparison of milk oligosaccharides pattern in colostrum of different horse breeds. J Agric Food Chem. 2015;63(19):4805-14.

50. Karav S, Salcedo J, Frese SA, Barile D. Thoroughbred mare's milk exhibits a unique and diverse free oligosaccharide profile. FEBS Open Bio. 2018;8(8):1219-29.

51. Kohn CW, Knight D, Hueston W, Jacobs R, Reed SM. Colostral and serum IgG, IgA, and IgM concentrations in Standardbred mares and their foals at parturition. J Am Vet Med Assoc. 1989;195(1):64-8.

52. Schneider F, Wehrend A. Quality assessment of bovine and equine colostrum - an overview. Schweiz Arch Tierheilkd. 2019;161(5):287-97.

53. Quigley JD, Lago A, Chapman C, Erickson P, Polo J. Evaluation of the brix refractometer to estimate immunoglobulin $\mathrm{G}$ concentration in bovine colostrum. J Dairy Sci. 2013;96(2):1148-55.

54. Peugnet P, Robles M, Wimel L, Tarrade A, Chavatte-Palmer P. Management of the pregnant mare and long-term consequences on the offspring. Theriogenology. 2016;86(1):99-109.

55. LeBlanc MM, Tran T, Baldwin JL, Pritchard EL. Factors that influence passive transfer of immunoglobulins in foals. J Am Vet Med Assoc. 1992;200(2):179-83.

56. Uniacke-Lowe T, Huppertz T, Fox PF. Equine milk proteins: chemistry, structure and nutritional significance. Int Dairy J. 2010;20(9):609-29.

57. Ullrey DE, Struthers RD, Hendricks DG, Brent BE. Composition of mare's milk. J Anim Sci. 1966;25(1):217-22.

58. Pastuszka R, Barlowska J, Litwinczuk Z. Allergenicity of milk of different animal species in relation to human milk. Postepy Hig Med Dosw (Online). 2016;70(0):1451-9.

59. Souroullas K, Aspri M, Papademas P. Donkey milk as a supplement in infant formula: benefits and technological challenges. Food Res Int. 2018;109:416-25.

60. Freeman KP. Cytological evaluation of the equine mammary gland. Equine Vet Educ. 2002;14(S5):97-8.

61. Brendemuehl JP. Mammary gland enlargement in the mare. Equine Vet Educ. 2010;20(1):8-9.

62. Petridis IG, Fthenakis GC. Mammary involution and relevant udder health management in sheep. Small Ruminant Res. 2019;181: 66-75.

63. Li M, Liu X, Robinson G, Bar-Peled U, Wagner KU, Young WS, et al. Mammary-derived signals activate programmed cell death during the first stage of mammary gland involution. Proc Natl Acad Sci U S A. 1997;94(7):3425-30.

64. Stewart TA, Hughes K, Stevenson AJ, Marino N, Ju AL, Morehead M, et al. Mammary mechanobiology: investigating roles for mechanically-activated ion channels in lactation and involution. J Cell Sci. 2000. https://doi.org/10.1242/jcs.248849. Epub ahead of print.

65. Chapman RS, Lourenco PC, Tonner E, Flint DJ, Selbert S, Takeda $\mathrm{K}$, et al. Suppression of epithelial apoptosis and delayed mammary gland involution in mice with a conditional knockout of Stat3. Genes Dev. 1999;13(19):2604-16.

66. Humphreys RC, Bierie B, Zhao L, Raz R, Levy D, Hennighausen L. Deletion of Stat3 blocks mammary gland involution and extends functional competence of the secretory epithelium in the absence of lactogenic stimuli. Endocrinology. 2002;143(9): 3641-50.

67. Kreuzaler PA, Staniszewska AD, Li W, Omidvar N, Kedjouar B, Turkson J, et al. Stat3 controls lysosomal-mediated cell death in vivo. Nat Cell Biol. 2011;13(3):303-9.

68. Sargeant TJ, Lloyd-Lewis B, Resemann HK, Ramos-Montoya A, Skepper J, Watson CJ. Stat3 controls cell death during mammary gland involution by regulating uptake of milk fat globules and lysosomal membrane permeabilization. Nat Cell Biol. 2014;16(11):1057-68. 
69. Lloyd-Lewis B, Krueger CC, Sargeant TJ, D'Angelo ME, Deery MJ, Feret R, et al. Stat3-mediated alterations in lysosomal membrane protein composition. J Biol Chem. 2018;293(12):4244-61.

70. Stein T, Morris JS, Davies CR, Weber-Hall SJ, Duffy MA, Heath $\mathrm{VJ}$, et al. Involution of the mouse mammary gland is associated with an immune cascade and an acute-phase response, involving LBP, CD14 and STAT3. Breast Cancer Res. 2004;6(2):R75-91.

71. O'Brien J, Lyons T, Monks J, Lucia MS, Wilson RS, Hines L, et al. Alternatively activated macrophages and collagen remodeling characterize the postpartum involuting mammary gland across species. Am J Pathol. 2010;176(3):1241-55.

72. O'Brien J, Martinson H, Durand-Rougely C, Schedin P. Macrophages are crucial for epithelial cell death and adipocyte repopulation during mammary gland involution. Development. 2012;139(2):269-75.

73. Dawson CA, Pal B, Vaillant F, Gandolfo LC, Liu Z, Bleriot C, et al. Tissue-resident ductal macrophages survey the mammary epithelium and facilitate tissue remodelling. Nat Cell Biol. 2020;22(5):546-58.

74. Hughes K, Wickenden JA, Allen JE, Watson CJ. Conditional deletion of Stat3 in mammary epithelium impairs the acute phase response and modulates immune cell numbers during postlactational regression. J Pathol. 2012;227(1):106-17.

75. Elder AM, Stoller AR, Black SA, Lyons TR. Macphatics and PoEMs in postpartum mammary development and tumor progression. J Mammary Gland Biol Neoplasia. 2020;25(2):103-13.

76. Quarrie LH, Addey CV, Wilde CJ. Programmed cell death during mammary tissue involution induced by weaning, litter removal, and milk stasis. J Cell Physiol. 1996;168(3):559-69.

77. Capuco AV, Li M, Long E, Ren S, Hruska KS, Schorr K, et al. Concurrent pregnancy retards mammary involution: effects on apoptosis and proliferation of the mammary epithelium after forced weaning of mice. Biol Reprod. 2002;66(5):1471-6.

78. Capuco AV, Akers RM, Smith JJ. Mammary growth in Holstein cows during the dry period: quantification of nucleic acids and histology. J Dairy Sci. 1997;80(3):477-87.

79. Capuco AV, Akers RM. Mammary involution in dairy animals. J Mammary Gland Biol Neoplasia. 1999;4(2):137-44.

80. Hurley WL. Mammary gland function during involution. J Dairy Sci. 1989;72(6):1637-46.

81. Davis FM, Lloyd-Lewis B, Harris OB, Kozar S, Winton DJ, Muresan L, et al. Single-cell lineage tracing in the mammary gland reveals stochastic clonal dispersion of stem/progenitor cell progeny. Nat Commun. 2016;7:13053.

82. Lloyd-Lewis B, Harris OB, Watson CJ, Davis FM. Mammary stem cells: premise, properties, and perspectives. Trends Cell Biol. 2017;27(8):556-67.

83. French R, Tornillo G. Heterogeneity of mammary stem cells. Adv Exp Med Biol. 2019;1169:119-40.

84. Rauner G, Ledet MM, Van de Walle GR. Conserved and variable: understanding mammary stem cells across species. Cytometry A. 2018;93(1):125-36.

85. Borena BM, Bussche L, Burvenich C, Duchateau L, Van de Walle GR. Mammary stem cell research in veterinary science: an update. Stem Cells Dev. 2013;22(12):1743-51.

86. Spaas JH, Chiers K, Bussche L, Burvenich C, Van de Walle GR. Stem/progenitor cells in non-lactating versus lactating equine mammary gland. Stem Cells Dev. 2012;21(16):3055-67.

87. Bussche L, Rauner G, Antonyak M, Syracuse B, McDowell M, Brown AM, et al. Microvesicle-mediated Wnt/beta-catenin signaling promotes interspecies mammary stem/progenitor cell growth. J Biol Chem. 2016;291(47):24390-405.

88. Robinson KA, Manning ST. Premature lactation and retention of a mummified fetus with live birth of the co-twin in a primiparous Morgan mare. Can Vet J. 2011;52(4):423-5.
89. McAfoos JL, Ellerbrock RE, Canisso IF. Fetal death associated with premature mammary gland development and lactation in a Mare treated with weekly injections of Long-acting progesterone. J Equine Vet Sci. 2019;81:102783.

90. Buehring GC. Short communication. Witch's milk: potential for neonatal diagnosis. Pediatr Res. 1982;16(6):460-2.

91. To T. Inappropriate lactation in a 15-year-old thoroughbred mare. Can Vet J. 2019;60(4):430-3.

92. McCue PM. Equine Cushing's disease. Vet Clin North Am Equine Pract. 2002;18(3):533-43.

93. Smiet E, Grinwis GCM, van den Top JGB. Sloet van Oldruitenborgh-Oosterbaan MM. Equine mammary gland disease with a focus on botryomycosis: a review and case study. Equine Vet Educ. 2012;24(7):357-66.

94. Arus Marti J, Fernandez S. Clinical approach to mammary gland disease. In: England G, von Heimendahl A, editors. BSAVA manual of canine and feline reproduction and neonatology. 2nd ed. United Kingdom: BSAVA British Small Animal Veterinary Association; 2010. p. 155-65.

95. Blaney BJ, McKenzie RA, Walters JR, Taylor LF, Bewg WS, Ryley MJ, et al. Sorghum ergot (Claviceps africana) associated with agalactia and feed refusal in pigs and dairy cattle. Aust Vet J. 2000;78(2):102-7.

96. Waret-Szkuta A, Larraillet L, Oswald IP, Legrand X, Guerre P, Martineau GP. Unusual acute neonatal mortality and sow agalactia linked with ergot alkaloid contamination of feed. Porcine Health Manag. 2019;5:24.

97. Tena-Betancourt E, Tena-Betancourt CA, Zuniga-Munoz AM, Hernandez-Godinez B, Ibanez-Contreras A, Graullera-Rivera V. Multiple extrauterine pregnancy with early and near full-term mummified fetuses in a New Zealand white rabbit (Oryctolagus cuniculus). J Am Assoc Lab Anim Sci. 2014;53(2):204-7.

98. Hughes K. Abdominal ectopic pregnancy and impaired postnatal mammary gland development, consistent with physiologic Agalactia, in a wild European rabbit, Oryctolagus cuniculus. Front Vet Sci. 2019;6:254.

99. Copetti MV, Santurio JM, Boeck AA, Silva RB, Bergermaier LA, Lubeck I, et al. Agalactia in mares fed with grain contaminated with Claviceps purpurea. Mycopathologia. 2002;154(4):199-200.

100. Evans TJ. The endocrine disruptive effects of ergopeptine alkaloids on pregnant mares. Vet Clin North Am Equine Pract. 2011;27(1):165-73.

101. Riet-Correa F, Rivero R, Odriozola E, Adrien Mde L, Medeiros RM, Schild AL. Mycotoxicoses of ruminants and horses. J Vet Diagn Investig. 2013;25(6):692-708.

102. Sweeney CR, Whitlock RH, Meirs DA, Whitehead SC, Barningham SO. Complications associated with Streptococcus equi infection on a horse farm. J Am Vet Med Assoc. 1987;191(11):1446-8.

103. Singh MP, Chanel KS. Treatment of agalactia in two mares. Equine Vet Educ. 1997;9(2):60-1.

104. Jackson PG. Equine mastitis: comparative lessons. Equine Vet J. 1986;18(2):88-9.

105. Munroe G, Campbell M, Munroe Z, Hanks M. Female reproductive tract. In: Munroe GA, Weese JS, editors. Equine clinical medicine, surgery, and reproduction. London: Manson Publishing Ltd; 2011. p. 242-325.

106. Prentice MW. Letter: mastitis in the mare. Vet Rec. 1974;94(16): 380 .

107. Roberts MC. Pseudomonas aeruginosa mastitis in a dry nonpregnant pony mare. Equine Vet J. 1986;18(2):146-7.

108. Pugh DG, Magnusson RA, Modransky PD, Darnton KR. A case of mastitis in a young filly. J Equine Vet Sci. 1985;5(3):132-4.

109. Perkins NR, Threlfall WR. Mastitis in the mare. Equine Vet Educ. 2002;14(S5):99-102. 
110. Gilday R, Lewis D, Lohmann KL. Mastitis in a neonatal filly. Can Vet J. 2015;56(1):63-5.

111. Corbeil LE, Morrissey JF, Leguillette R. Is Corynebacterium pseudotuberculosis infection (pigeon fever) in horses an emerging disease in western Canada? Can Vet J. 2016;57(10):1062-6.

112. Belli CB, Fonte JS, Torres LN, Gondin MR, Maiorka PC, Fernandes CB. Mammary botryomycosis: two concomitant cases in mares: case report. Arquivo Brasileiro de Medicina Veterinária e Zootecnia. 2018;70:342-6.

113. Walker RL, Johnson BJ, Jones KL, Pappagianis D, Carlson GP. Coccidioides immitis mastitis in a mare. J Vet Diagn Investig. 1993;5(3):446-8.

114. Wilson JH, Olson EJ, Haugen EW, Hunt LM, Johnson JL, Hayden DW. Systemic blastomycosis in a horse. J Vet Diagn Investig. 2006;18(6):615-9.

115. Greiner EC, Mays MB, Smart GC Jr, Weisbrode SE. Verminous mastitis in a mare caused by a free-living nematode. J Parasitol. 1991;77(2):320-2.

116. Wilkins PA, Wacholder S, Nolan TJ, Bolin DC, Hunt P, Bernard $\mathrm{W}$, et al. Evidence for transmission of Halicephalobus deletrix $(\mathrm{H}$ gingivalis) from dam to foal. J Vet Intern Med. 2001;15(4):412-7.

117. McGladdery AJ. Differential diagnosis and treatment of diseases of the equine mammary gland. Equine Vet Educ. 2002;14(S5):94 6.

118. McKenzie RA, Brown OP. Avocado (Persea americana) poisoning of horses. Aust Vet J. 1991;68(2):77-8.

119. Knottenbelt DC, Pascoe RP. Color atlas of diseases and disorders of the horse. Philadelphia: Mosby, An affiliate of Elsevier Science Limited; 1994. p. 393-5.

120. Harman RM, Das SP, Bartlett AP, Rauner G, Donahue LR, Van de Walle GR. Beyond tradition and convention: benefits of nontraditional model organisms in cancer research. Cancer Metastasis Rev. 2020. https://doi.org/10.1007/s10555-020-09930-6.

121. Spadari A, Valentini S, Sarli G, Spinella G, Millanta F. Mammary adenoma in a mare: clinical, histopathological and immunohistochemical findings. Equine Vet Educ. 2008;20(1):4-7.

122. Acland HM, Gillette DM. Mammary carcinoma in a mare. Vet Pathol. 1982;19(1):93-5.

123. Kato M, Higuchi T, Hata H, Ishikawa Y, Kadota K. Lactalbuminpositive mammary carcinoma in a mare. Equine Vet J. 1998;30(4): $358-60$

124. Cheng SA, Liang LZ, Liang QL, Huang ZY, Peng XX, Hong XC, et al. Breast cancer laterality and molecular subtype likely share a common risk factor. Cancer Manag Res. 2018;10:6549-54.

125. Mokone-Fatunla DH, Koto MZ, Becker JHR, Bondo M, Mundawarara S. Laterality of breast cancer at Dr George Mukhari academic hospital. S Afr J Surg. 2019;57(3):56.

126. Kobayashi S, Sugiura H, Ando Y, Shiraki N, Yanagi T, Yamashita $\mathrm{H}$, et al. Reproductive history and breast cancer risk. Breast Cancer. 2012;19(4):302-8.

127. Seahorn TL, Hall G, Brumbaugh GW, Honnas CM, Lovering SL, Snyder JR. Mammary adenocarcinoma in four mares. J Am Vet Med Assoc. 1992;200(11):1675-7.

128. Prendergast M, Bassett H, Larkin HA. Mammary carcinoma in three mares. Vet Rec. 1999;144(26):731-2.

129. Sabiza S, Rezaie A, Naddaf H, Sajjadi Dezfouli M, Kaamyab NM. Surgical treatment of a mammary gland comedocarcinoma in an Arabian mare: post-operative management, and histopathological and immunohistochemical features. Equine Vet Educ. 2020. https://doi.org/10.1111/eve.13302.

130. Parra LA, Paredes MP. Carcinoma de glandula mamaria en una yegua criolla Colombiana. Reporte de caso. Revista de la Facultad de Medicina Veterinaria y de Zootecnia. 2016;63:135-46.

131. Boyce SD, Goodwin SL. Mammary gland neoplasia in a Canadian mare: challenges of diagnosis and treatment in a rural setting. Can Vet J. 2017;58(6):628-30.
132. Brito MF, Seppa GS, Teixeira LG, Rocha TG, França TN, Hess TM, et al. Mammary adenocarcinoma in a mare. Ciência Rural. 2008;38:556-60.

133. Munson L. Carcinoma of the mammary gland in a mare. J Am Vet Med Assoc. 1987;191(1):71-2.

134. Shank AM. Mare mammary neoplasia: difficulties in diagnosis and treatment. Equine Vet Educ. 2009;21(9):475-7.

135. Reppas GP, McClintock SA, Canfield PJ, Watson GF. Papillary ductal adenocarcinoma in the mammary glands of two horses. Vet Rec. 1996;138(21):518-9.

136. Foreman JH, Weidner JP, Parry BW, Hargis A. Pleural effusion secondary to thoracic metastatic mammary adenocarcinoma in a mare. J Am Vet Med Assoc. 1990;197(9):1193-5.

137. Goldschmidt MH, Pena L, Zappulli V. Tumors of the mammary gland. In: Meuten DJ, editor. Tumors in domestic animals. Ames: John Wiley \& Sons Inc; 2017. p. 723-65.

138. Gamba CO, Araujo MR, Palhares MS, Garbin LC, Maranhao RP, Cassali GD, et al. Invasive micropapillary carcinoma of the mammary glands in a mare. Vet Q. 2011;31(4):207-10.

139. Bussche L, Harms C, Buckles EL, Whelchel D, Brosnahan M, Van de Walle GR. Carcinoma of the mammary gland in a mare. Equine Vet Educ. 2017;29(7):370-5.

140. Watson CJ, Miller WR. Elevated levels of members of the STAT family of transcription factors in breast carcinoma nuclear extracts. Br J Cancer. 1995;71(4):840-4.

141. Dechow TN, Pedranzini L, Leitch A, Leslie K, Gerald WL, Linkov I, et al. Requirement of matrix metalloproteinase-9 for the transformation of human mammary epithelial cells by Stat3C. Proc Natl Acad Sci U S A. 2004;101(29):10602-7.

142. Alvarez JV, Febbo PG, Ramaswamy S, Loda M, Richardson A, Frank DA. Identification of a genetic signature of activated signal transducer and activator of transcription 3 in human tumors. Cancer Res. 2005;65(12):5054-62.

143. Karcher LF, Le Net JL, Turner BF, Reimers TJ, Tennant BC. Pseudohyperparathyroidism in a mare associated with squamous cell carcinoma of the vulva. Cornell Vet. 1990;80(2):153-62.

144. Reesink HL, Parente EJ, Sertich PL, Engiles JB. Malignant fibrous histiocytoma of the mammary gland in a mare. Equine Vet Educ. 2009;21(9):467-72.

145. Mendes LCN, de Araujo MA, Bovino F, Rozza DB, Machado GF, Cadioloi FA, et al. Clinical, histological and immunophenotypic findings in a mare with a mammary lymphoma associated with anaemia and pruritis. Equine Vet Educ. 2011;23(4):177-83.

146. MacEachern KE, McKay JS, Hewicker-Trautwein M. Malignant mammary melanoma in a young mature thoroughbred mare. Equine Vet Educ. 2001;13(2):68-71.

147. Murad MH, Asi N, Alsawas M, Alahdab F. New evidence pyramid. Evid Based Med. 2016;21(4):125-7.

148. Dean R. How to read a paper and appraise the evidence. In Practice. 2013;35(5):282-5.

149. Valle E, Pozzo L, Giribaldi M, Bergero D, Gennero MS, Dezzutto $\mathrm{D}$, et al. Effect of farming system on donkey milk composition. J Sci Food Agric. 2018;98(7):2801-8.

150. Miraglia N, Salimei E, Fantuz F. Equine milk production and valorization of marginal areas-a review. Animals (Basel). 2020;10:353.

151. Nagy D, Gillis CMC, Davies K, Fowden AL, Rees P, Wills JW, et al. Developing mammary terminal duct lobular units have a dynamic mucosal and stromal immune microenvironment. bioRxiv. 2020;2020:11.05.369843. https://doi.org/10.1101/2020. 11.05.369843.

Publisher's Note Springer Nature remains neutral with regard to jurisdictional claims in published maps and institutional affiliations. 